\title{
Branches Investigation of the Religious Beliefs in Various Terms of Variables of the Turkish National Team Athletes in Individual
}

\author{
Oğuzhan Altungül \\ Correspondence: Oğuzhan Altungül, Fırat University, Faculty of Sport Sciences, Elazığ, Turkey.
}

Received: February 21, 2017

doi:10.11114/jets.v5i4.2293
Accepted: February 28, $2017 \quad$ Online Published: March 20, 2017

URL: https://doi.org/10.11114/jets.v5i4.2293

\begin{abstract}
In general, and broadest sense, the word religion; "No matter what submission to a higher authority, to accept orders and provisions that arising from this authority as the rules that must be followed, when the prize comply with these rules will be taken when the penalty point against is the general name of a living system into believing the area. The study's population is the athletes participating in the competition in individual branches of the Turkish national team. The sample of the study is 50 females and 102 males totally 152 national athletes who representing Turkish National Team in individual branches such as Boxing (46), Taekwondo (30), Wrestling (76). Personal Information Survey and Religious Belief Scale were used in collecting the data. When the data analyzed statistically, it is determined that there is significant differences in terms of gender, marital status and level of education. As a result, it is emerged that, religious is known by everyone unheeded by someone but believed to be in every respect and worshipping in availability by the elite athletes and in terms of sports and athletes it is different in normal people.
\end{abstract}

Keywords: athletes, national team athletes, religious beliefs

\section{Introduction}

Due to the creation humankind is questioning himself and researching constantly, ever since the existence of o people they accepted as god and believed, the types of materials such as buildings, animals, plants and different objects. These people assumed that the god they believe provides their safety and they made prayers in various ways. While it is a seeing situation that there is faith where human being is in today's society, especially for people who do this sport at top level it is becoming a little more meaningful and different. We can make fallowing definitions about religion which is so important for mankind.

The concept of religion is one of the most debated subjects of the sociology of religion from the beginning. It is emerges as a problematic area that the definitions of the religion as many sociological concepts; depending on what we mean by religion, definitions vary. Western theologians explains religion generally in two ways which is substantive/essentialist and functional (Davit, 2006; Kurt, 2008). In general, and broadest sense, the word religion; "No matter what submission to a higher authority, to accept orders and provisions that arising from this authority as the rules that must be followed, when the prize comply with these rules will be taken when the penalty point against is the general name of a living system into believing the area (Karaköse, 2006). Religion in Islam is, an institution that God puts and consisting of members of the beliefs and behavior that leads to salvation in this world and hereafter (Taplamacioglu, 1983). According to another definition, it shows the way to happiness to people. It will signify to access their happiness. Tells what is the purpose and objective of creation and, what to do to worship to God. People will be referred to the works of charity (Akseki, 1966). Belief is an integral part of religion, which is one of the central concepts of religion and theologians generally emphasize two issues while defining religion. First one is belief or beliefs, second one is the motive applications which arising from this belief or beliefs. Belief and faith: these two concepts have a different meaning in other languages as it is sometimes used interchangeably with in Turkish too (Kaylkl1k, 2005). Belief is explained in Turkish Language Society dictionary; "1. Wholeheartily engaged to an opinion, 2. A trust to someone, a sense of faith, 3. Believe a God and a religion". While Sport that the other main subject of our study has various definitions by scholars it could be explained generally.

Sports, is a cultural phenomenon that developing the abilities achieved while people converting their natural environment to social environment, individual or collective leisure activities within the scope of or to receive the full time by being professionalized, socializing, integrate with society, developing mental and physical structure, 
competitive and solidarity (Ertürk, 1999). Sports, according to the other definitions, is a biological, educational and social endeavor which improves individual's physical activity and motor skills, psychological and social aspects in certain regulations and aims these features compete in characteristic rules (İnal, 2003).Sports, is an integrative activity that society could not ignore universal indispensable and cannot interrupt. Thus, by civilization in the world sporting event reveals the need to spread sport extensively basically (Sunay, 2002).Sports is phenomenon that brings people together and make them compete in the same guidelines, regardless of their religion, language, race, level of education and social status and capable of providing communication between different societies, can enter deep into the social life and can also be shaped by social structure. Sports, adversely affected from time to time the by social structure change, from ancient times to the present day and it has become a universal language that can be spoken throughout the world as in music (Bayraktar, 2003).

There is a relationship between sports and religion from the human existence; both have an impact which directing people to some physical and emotional social activities between them. Religion and sport has a certain relationship even if it is far, because sports sciences is at equal distance to all disciplines, it is quite natural that the people who implementing and enforcing the sports have a belief. It is a mutual interaction between sports and religion. Sport is directly connected with religion as one of the human behavior and self-expression. Religion used the sports influence and power on wide audience, since the industrial revolution by establishing of various clubs. In fact both institution makes people feel at peace, happy to be around people and fosters a sense of being under a common denominator (Hasirc1, 2012). Today, sport is done by a lot of people for different purposes. Individuals who make sport as a job considered as professional athletes, in order to gain financially depended to certain organization or as an individual, by a written contract with the club (Alnıak, 2008). Professional or amateur athletes can be participate in competitions as the country's national teams that they borne and lived, they can participate other country teams too. We can define the national athletes as fallow: the athletes, who invited by the technical team or federation of that branch, to compete in the name of national teams in competitions and organizations.

The purpose of this study is to investigate religion belief level of athletes, who is in national teams of the countries, in various terms of variables and to determine the effect of religion and belief on elite athlete's success.

\section{Methodology}

\subsection{Population and Sample}

The study's population is the athletes participating in the competition in individual branches of the Turkish national team. The sample of the study is 50 females and 102 males totally 152 national athletes who representing Turkish National Team in individual branches such as Boxing (46), Taekwondo (30), Wrestling (76).

\subsection{Data Gathering Tools}

Personal Information Survey and Religious Belief Scale were used in collecting the data.

\subsection{Personal Information Survey}

At the independence variable part of this study, open-ended questions were asked to determine gender, branch, education level and marital status.

Religious Fundamentalism Scale which developed by Altemeyer and Hunsberger (2004)used by translating in Turkish and considering the faith principles of Islam and this scale is used in this study to determine the faith level of individuals as "Religious Belief Scale".

Questions of Religious Belief Scale, which is prepared as fife point Likert types, answered by choosing strongly agree undecided, disagree and strongly disagree. Scale has 12 questions that six of the questions have straight or direct and six of the questions have conversely turned phrases. Half of the questions have reverse feature for checking the bias of answers. Direct phrases express positive, reversed phrases express negative faiths. Choices that marked for the direct phrases as strongly agree, agree, undecided, disagree and strongly disagree, respectively scored as 5, 4, 3, 2, 1 and in the reversed phrases this score is like 1, 2, 3, 4, 5. High scores obtained from the scale indicate the high level of religious belief. The lowest score from the scale is 12 and the highest score 60 . In the reliability research made on this study's data, both test-half test and Cronbach Alpha reliability coefficient was found as 0.78 . The result of the factor analyses that made for validity, it was observed that 1. 2. 4. 5. 7. 8. 9. 10. and 12. Items factor charge collecting in the first factor (religious teachings); 3. 6. and 11. Items factor charge collecting in the second factor (categorical thinking). Also it is found that correlation coefficient between item scores and total score is changing between $0.25-0.68$ and it is significant at $\mathrm{p}<0.01$.

The scale that developed by Altemeyer and Hunsberger adopted to Turkish and Turkish Society by Sezer's study (2008), reliability and validity studies have been conducted. According to the results obtained, it can say that the Religious Belief Scale is valid and reliable (Abdülvahit, 2008). 


\section{Results}

The findings obtained by the researchers evaluated in the expert opinion, out of the substance exhibiting differences in mean statistical results evaluate are made.

Table 1. T-test statistical values of religious beliefs scale score distribution regarding gender variable

\begin{tabular}{llllll}
\hline Gender & \multicolumn{1}{c}{$\mathrm{n}$} & $\overline{\mathrm{x}}$ & $\mathrm{sd}$ & $\mathrm{t}$ & $\mathbf{p}$ \\
\hline Female & 50 & 44.5000 & 6.96126 & -3.027 & $0.00^{*}$ \\
Male & 102 & 48.4216 & 7.75547 & &
\end{tabular}

At Table 1 when the religious belief scale scores investigated regarding the gender variable of national athletes, it was observed that male's score means are higher than the female's means. This situation was considered significant according to t-test results from the statistical angle $(\mathrm{p}>0.05)$.

Table 2. T-test statistical values of religious beliefs scale score distribution regarding marital status variable.

\begin{tabular}{llllll}
\hline M.Status & $\mathrm{n}$ & $\overline{\mathrm{x}}$ & $\mathrm{sd}$ & $\mathrm{t}$ & $\mathrm{p}$ \\
\hline Married & 32 & 55.6875 & 4.46808 & \multirow{2}{*}{8.614} & $0.00 *$ \\
Single & 120 & 44.8500 & 6.72341 & & \\
\hline
\end{tabular}

At table 2 when the religious belief scores investigated regarding the marital status of national athletes, it was observed that married athletes score means $(\overline{\mathrm{x}}=55.68)$ are higher than the single athletes score means $(\overline{\mathrm{x}}=44.85)$. This difference between scores is statistically significant.

Table 3. Anova statistical values of religious beliefs scale score distribution regarding sport branch variable.

\begin{tabular}{llllll}
\hline Branches & $\mathrm{n}$ & $\overline{\mathrm{x}}$ & $\mathrm{sd}$ & $\mathrm{f}$ & $\mathrm{p}$ \\
\hline Box & 46 & $49.5217^{*}$ & 6.30252 & & \\
Wrestling & 76 & $42.3158^{*}$ & 5.60050 & & \\
Taekwondo & 30 & $55.6667^{*}$ & 4.60385 & 65.980 & $0.00^{*}$ \\
Total & 152 & 47.1316 & 7.70541 & &
\end{tabular}

At table 3 when the religious belief scores investigated regarding sport branch of national athletes, it was observed that belief score means is difference by the sport branches. While it seems it goes higher to lower as Taekwondo ( $\overline{\mathrm{x}}=55.66)$, Box $(\bar{x}=49.52)$ and Wrestling $(\bar{x}=42.31)$, this differentiation was accepted statistically significant and the differences are in all branches was determined by analysis of Anova ( $\mathrm{p}>0.05)$.

Table 4. T-test statistical values of religious beliefs scale score distribution regarding education level variable.

\begin{tabular}{llllll}
\hline Education & $\mathrm{n}$ & $\overline{\mathrm{x}}$ & $\mathrm{sd}$ & $\mathrm{t}$ & $\mathrm{p}$ \\
\hline Mid.School & 78 & 44.3077 & 6.84960 & & \\
Col. and High & 74 & 50.1081 & 7.47153 & & $0.00^{*}$ \\
\hline
\end{tabular}

At Table 4 when the religious belief scale scores investigated regarding the gender variable of national athletes, it was observed that collage and higher education score means are higher than the middle school means. This situation was considered significant according to t-test results from the statistical angle $(\mathrm{p}>0.05)$.

\section{Discussion}

Belief is regarded by many people and they worship can be seen in different ways to different objects. There are variables the level of belief among people, while some show commitment at a high level; some are never able to express that belief. According the research that made on the level of religion belief among athletes, it is known that athletes are more senior than normal people's religious belief.

At Table 1 when the religious belief scale scores investigated regarding the gender variable of national athletes, it was observed that males score means are higher than the females means $(\overline{\mathrm{x}}=48.42)$. It can be shown that in the study made by Acar et all. (1996) A large proportion of pious are men, this supports our study. In the study which made by another researcher Bayyigit (2001) bon university students to engage in prayer and fasting worship, he showed that male students numerical superiority is more than the female students In reviewing the literature on this subject it has been faced with the research reached a different conclusion (Bayyigit, 2001). In his research Beit's (1975) findings reached the opposite direction of our study. Beit specified that, many times there are significant differences between male and female piety and religious, women are more often stated qualitatively and quantitatively, more worship and read the 
Holly Book and they even add an emotional dimension to religion (Guiora, et all. 1975). In the study which made by Karaca (2008), he concluded that, there is no change in orientation of male and female students values. The results obtained in scientific studies include work outside of Turkey, female are more religious than men (Cirhinlioglu, 2011).Different results by the studies considered as important differentiation findings in terms of gender between the athlete and non-athlete individuals.

At Table 2 when the religious belief scores investigated regarding the marital status of national athletes, it was observed that married athlete's score means ( $\bar{x}=55.68)$ are higher than the single athlete's score means $(\bar{x}=44,85)$. In studies made on related to marital status values, married men value levels are higher than the singles in several studies (Karaca, 2008). In a study that made by Voltan, and Yildırım (1996), he reached the results that married people are more religious than the singles and in the same study he showed that married male are more religious than the married female, this supports our study.

At table 3 when the religious belief scores investigated regarding sport branch of national athletes, it was observed that belief score means is difference by the sport branches. While it seems it goes higher to lower as Taekwondo ( $\overline{\mathrm{x}}=55.66)$, Box $(\overline{\mathrm{x}}=49.52)$ and Wrestling $(\overline{\mathrm{x}}=42.31)$, this differentiation was accepted statistically significant. In parallel with our work, Bölükbaşı and Kılcıgil (2004) concluded that, in the study on religiosity sizes and Turkish national team in taekwondo and swimming branch female athletes participated, the national women's sport taekwondo athletes feel themselves as more religious $(\% 70)$ and $\mathrm{p}<0.01)$ (Bölükbaş1, \& Kılcıgil, 2004). These results in the emergence of Korean martial arts originated in the Far East and to be a sport and it may also have been influential in the mean struggle with their people (Ramazanoğlu, 2003). In addition, when the meaning of the word Taekwondo sports analyzed do, the words last of the syllable means: Morality, faith, kindness, respect, art, information maturation of the body and soul (GSGM, 2013).

At Table 4 when the religious belief scale scores investigated regarding the gender variable of national athletes, it was observed that collage and higher education score means are higher than the middle school means. In another study of our results as our vice versa, an increase of the level of education decreases it was seen very religious and pious; During the level of education increases, it is concluded that, people have a reduction in the level of belief depending on the cause-and-effect relationship in many cases (Voltan, \&Yıldırım, 1996). In his research, another researcher Uysal (1995) concluded, the increase in the educational level of the drop shown by piety has a parallel dimension. Our research inversely proportional to the occurrence of these results, the subjects participated in the research group, may have the effect that individuals who participate in sports at a high level.

\section{Conclusion}

As a result, understanding of religion in Turkey and show differences between groups of people, misinterpretation can arise between people religious factions. But senior sports people engaged in the same religious values, may show differences based on age or the status of people, this condition is thought to make a positive impact on motivation of these people before and during competition. This research is important to determination of the current situation and it is the first study in its area. The results of this research and models are thought to contribute to the researchers, who will research on athletes.

\section{Suggestions}

Expert people in the field could be appointed in order to experience the sense of religion in the right way in top-level individual sports athletes. Expert people could be appointed in psychology, for a better understanding of the religion and motivation by athlete. Physical facilities should be created that athlete to be able to perform all kinds of religious beliefs. This research is important to determination of the current situation and it is the first study in its area. The results of this research and models are thought to contribute to the researchers, who will research on athletes.

\section{References}

Abdulvahit, S. (2008). Development of the University Students Sample faith and religious fundamentalism A Study on the Relationship Between, Unpublished PhD thesis. İzmir: Dokuz Eylül University.

Akseki, H. (1966). Islamic Religious. Religious Affairs Pub (p: 7), Ankara.

Alniak, T. (2008). Developments in Sports Law Concept of Professional Footballers Some private Disputes.

Altemeyer, B. (2004). Hunsberger BA Revised Religious Fundamentalism Scale: The Short and Sweet of It. The International Journal for the Psychology of Religion, 14(1), 47-54. https://doi.org/10.1207/s15327582ijpr1401_4

Bayraktar, C. (2003). Impact of Social Structure Features to Sports. Journal of Uludağ University Faculty of Education, $17(1), 19-36$.

Bayyigit, M. (2001). Youth and Religion, A Comparative Research on University Youth, (p: 101-122), Ankara. 
Bolukbasi, Z., \& Kilcigil, E. (2004) Dimensions of Religious Devotion SportsWoman in Taekwondo and Swimming Branch. Journal of Sports Science, 2(2) 61-72.

Cirhinlioglu, F. G. (2011). Is It More Religious Men or Women. Journal of World of Turks, 3(1).

Davie, G. (2006). Sociology of Religion: Development and Theoretical Studies. Sociology of Religion. Classical and Contemporary Perspectives, Editors: B. Singh and IM. Capcioglu, Line Bookstore Konya, (p: 103).

Ertürk. Y. (1999). Sports Comparative Study of Different Social Groups According to Advocacy (Sivas sample).

GSGM. (2013) Department of health affairs, Sports Injuries and Solutions in Taekwondo.

Guiora, A. Z., Paluszny, M., Beit-Hallahmi, B., Catford, J. C., Cooley, R. E., \& Dull, C. Y., (1975). Language and person studies in language behavior. Language learning, 25(1), 43-61.

https://doi.org/10.1111/j.1467-1770.1975.tb00108.x

Hasırc1, S. (2012). Turkish Sports Agency Sports and Religion.

Inal, A. N. (2003). Physical Education and Sports Science.1st edition. Nobel Release Distribution, Ankara.

Karaca, R. (2008). Value Orientations of the Theology Faculty Student. Faculty of Theology Journal, Istanbul.

Karakose, S. (2006). To Recognize Individuals in Religion Education.Mavi Publishing, (p: 15).

Kayıklık, H. (2005). Faith and doubt from psychologica1 perspective. Journal of The Faculty of Divinity of Ankara University, 46(1), 133-155.

Kurt, A. (2008). Religion in Theological Perspective Definition and sociological problems. Journal of Uludag University Faculty of Theology, 17(2), 73-93.

Ramazanoglu, F. (2000). Taekwondo theory, technical and socio-cultural training. Ozal Printing press, Istanbul.

Sunay, H. (2002). Contemporary Sports Manager Expanding the Scope of Role and Importance of Sport in Turkey. 7th International Congress of Sports Sciences, Antalya.

Taplamacioglu, M. (1983). Sociology of Religion. A.Ü.I.F. Publishing (p: 50), Ankara.

Unpublished Master thesis. Sivas: Cumhuriyet University.

Uysal, V. (1995). An Islamic Religiosity Scale Pilot Study 8. Islam and Secularism Issue Special Issue, M.Ü. faculty of Theology, 3(4), Istanbul.

Voltan, A. N., Yıldırım, I., \& Ergene T. (1996). Investigation Some Variables in Terms of Religiosity Level of Individuals. Hacettepe University Faculty of Education Journal, 12, 45-56.

\section{Copyrights}

Copyright for this article is retained by the author(s), with first publication rights granted to the journal.

This is an open-access article distributed under the terms and conditions of the Creative Commons Attribution license which permits unrestricted use, distribution, and reproduction in any medium, provided the original work is properly cited. 